\title{
Biologically-Induced Precipitation of Minerals in a Medium with Zinc Under Sulfate-Reducing Conditions
}

\author{
DOROTA WOLICKA ${ }^{1}$, ANDRZEJ BORKOWSKI ${ }^{1}$, URSZULA JANKIEWICZ², WOJCIECH STĘPIEN ${ }^{3}$ \\ and PAWEŁ KOWALCZYK ${ }^{4,5 *}$ \\ ${ }^{1}$ Institute of Geochemistry, Mineralogy and Petrology, Faculty of Geology, University of Warsaw, Warsaw, Poland \\ ${ }^{2}$ Department of Biochemistry, Faculty of Agriculture and Biology, Warsaw University of Life Sciences - SGGW, \\ Warsaw, Poland; ${ }^{3}$ Department of Soil Sciences, Faculty of Agriculture and Biology, Warsaw University \\ of Life Sciences - SGGW, Warsaw, Poland; ${ }^{4}$ Department of Microbial Biology, Faculty of Agriculture and Biology, \\ Warsaw University of Life Sciences - SGGW, , Warsaw, Poland; ${ }^{5}$ Bionicum LTD, Warsaw, Poland
}

Submitted 14 November 2013, revised 6 September 2014, accepted 27 February 2015

\begin{abstract}
Sulfate-reducing microbial communities were enriched from soils collected in areas with crude-oil exploitation. Cultures were grown in modified Postgate $\mathrm{C}$ medium and minimal medium, with ethanol or lactate as an electron donor. The batch cultures were grown with addition of zinc in concentrations of 100-700 mg/l. A lack of increased protein concentration in the solutions compared with the control batch, was noted in cultures containing over $200 \mathrm{mg} \mathrm{Zn}{ }^{2+} / 1$. The $16 \mathrm{~S}$ rRNA method was applied to determine the specific composition of the selected microorganism communities. The analysis indicated the presence of Desulfovibrio spp., Desulfobulbus spp. and Desulfotomaculum spp. in the communities. Diffractometric analysis indicated the presence of biogenic sphalerite in cultures with 100 and $200 \mathrm{mg} \mathrm{Zn}^{2+} / \mathrm{l}$ and elemental sulfur in cultures with $200 \mathrm{mg} \mathrm{Zn}{ }^{2+} / 1$. Other post culture sediments (300-700 mg Zn $\left.{ }^{2+} / \mathrm{l}\right)$ contained only hopeite $\left[\mathrm{Zn}_{3}\left(\mathrm{PO}_{4}\right)_{2} \cdot 4 \mathrm{H}_{2} \mathrm{O}\right]$ formed abiotically during the experiment, which was confirmed by studies of the activity of sulfate-reducing microbial communities.
\end{abstract}

Ke y word s: biogenic precipitation, biomineralization, $16 \mathrm{~S}$ rRNA, sulfate-reducing bacteria, zinc

\section{Introduction}

In the topmost part of the lithosphere, zinc is a trace element that poses a serious hazard to the environment. Heavy metals, including zinc, migrate in the hypergenic zone during various petrogenetic and geochemical processes, resulting in their concentration but equally often in their dispersion. The environmental issue caused by the migration of heavy metals, including zinc, is complex. On the one hand, such migration causes disappearance of the metals from ore beds, but on the other hand, the metals appear in increasing concentrations in the exploitation area. Ore exploitation and further treatment processes linked with the utilization of the raw ore deposit result in the formation of post-exploitation and technological wastes containing significant amounts of metals. Industrial wastes containing zinc are generally formed during the production of batteries, paints, plastics, polymer stabilizers as well as in printing enterprises (Fosmire, 1990). Environments contaminated by zinc may be harmful. Effluents that are naturally generated in waste dumpsites often discharge to surface water reservoirs, watercourses and soil, caus- ing potential hazard to the environment. There are also areas with concentrations of selected metals, e.g., in areas of crude-oil exploitation. At present, there is an urgent need to apply processes that will allow recycling of heavy metals from wastes and poor ores and at the same time will minimize their negative influence on living organisms. Working out of an effective method of zinc recycling, e.g., from spoil tips, requires knowledge of the geochemical and mineral-forming processes taking place in the environment that will allow determination of the stability of the resulting mineral phases. Densification of heavy metals and their forms in soils depends on numerous factors of the physical and chemical environment, e.g., the magnitude of adsorption, the presence of humic acids and other soil components, the $\mathrm{pH}$, the redox potential and others. Additionally, studies should include the role of microorganisms, especially sulfate-reducing bacteria (SRB), in the formation of secondary metal sulfides. SRB are a diverse group of anaerobic microorganisms that have the ability to reduce oxidized sulfur compounds and to oxidize organic compounds (Postgate, 1984; Hao et al., 1996). They are considered to be the main producers of

\footnotetext{
* Corresponding author: P. Kowalczyk, Bionicum LTD, Warsaw, Poland; e-mail: pawel.kowalczyk@bionicum.com.pl
} 
hydrogen sulfide in the biosphere. Sulfides that are produced during dissimilatory sulfate reduction may react with metals, including zinc, creating various secondary sulfides. In recent years, SRB have been applied to neutralize acid mine water, which may contain heavymetal cations; and sparingly soluble metal sulfides are formed under these conditions (Jonson and Halleberg, 2003; Luptakova and Kusnierova, 2005; Kaksonen and Puhakka, 2007; Ong et al., 2010). Application of SRB to acid mine drainage may remove heavy metals such as zinc from this environment. A few authors have asked why different kinds of minerals are formed during biological processes, and when and what influences these processes. Knowledge of biogeochemical interactions in the environment allows us to describe the processes and to predict them. It was long considered that the high toxicity of many heavy metals affects microbiological precipitation of sulfides by SRB. This opinion changed in 1961 when Becking and Moore (1961) carried out an experiment in which salts of selected metals were added to a medium with a composition close to that of marine water. The results explicitly pointed to SRB participation in the formation of secondary mineral phases because the post-culture sediments contained sphalerite $(\mathrm{ZnS})$, a product of $\mathrm{SO}_{4}{ }^{2-}$ and $\mathrm{ZnCO}_{3}$ biotransformation. Taking into account the possible geochemical reactions, it can be assumed that in sedimentary settings, heavymetal ions are largely adsorbed by clay minerals and form metal-organic compounds. All these processes lead to decrease of the toxicity level of a given metal by decreasing its concentration in the solution, although the metal is still capable of reactions with hydrogen sulfide and sulfide formation. On the other hand, the products of biochemical processes may include extracellular polymeric substances (EPS), which are mixtures of polysaccharides, mucopolysaccharides and proteins produced by microorganisms. The composition of EPS produced by SRB may be modified by the presence of different forms of organic matter in the environment, which may influence the increase of the metal-binding capacity (Zinkevich et al., 1996) So far, the microbiological, geochemical and mineralogical processes leading to the formation of $\mathrm{ZnS}$ in environments impacted by human activities remain unrecognized. Spherical aggregates of sphalerite are commonly observed in biofilm structures where anaerobic conditions prevail. These zones are usually dominated by SRB that are relatively tolerant to oxygen, representing the families Desulfobacteraceae and Desulfovibrionaceae (Labrenz et al., 2000; Vainshtein et al., 1992). The precipitation of sphalerite at low temperatures may takes place in mine-water environments (Ledin and Pedersen, 1996; Drury, 1999; Moreau et al., 2004). In order to determine the effect of zinc concentration on the activity of selected groups of microorganisms, experiments were performed in which zinc chloride was added at various concentrations to SRB cultures. There are only a few reports that describe both the influence of SRB on the formation of mineral phases that contain zinc and its effect on SRB activity.

The present study focused on the role of SRB isolated from soils with increased zinc concentrations, collected in areas of crude-oil exploitation, in the formation of zinc sulfide at high concentrations of the metal. It also focused on the toxicity of zinc in relation to sulfate reducing microbial communities in batch cultures containing easily accessible carbon sources for SRB, i.e., lactate or ethanol.

\section{Experimental}

\section{Materials and Methods}

Selection and isolation of sulfate-reducing microbial communities. The microorganisms were enriched from soil polluted by crude oil and oil-derived products from SE Poland. SRB are commonly found in soils contaminated by crude oil due to the ability to metabolize the oil derived products (Feio et al., 2004). In tested soils samples, C total was $3.2 \%$, total S was about $120 \mathrm{mg} / \mathrm{kg}$ dry weight, total $\mathrm{N}$ was about $700 \mathrm{mg} / \mathrm{kg}$, and $\mathrm{Zn}^{2+}$ was $92 \mathrm{mg} / \mathrm{kg}$. In the tested soil samples the $\mathrm{Zn}^{2+}$ ions were only determined. First, an Easycult $S$ test (Orion Diagnostica Espoo of Finland) was made to check for the presence of sulfidogenic microorganism communities; next, the microorganisms were selected using the microcosm method. Soil samples $(10 \mathrm{~g})$ were inserted in $100-\mathrm{ml}$ flasks and covered with $80 \mathrm{ml}$ of the particular medium. Two types of media were applied: a modified Postgate $\mathrm{C}$ medium (without yeast extract and sodium citrate) and a minimal medium with lactate or ethanol as electron donors. The flasks were tightly closed and incubated in darkness for 6 weeks at room temperature $\left(\right.$ about $22^{\circ} \mathrm{C}$ ) in order to select anaerobic, sulfidogenic microorganism communities capable of simultaneous biodegradation of the applied carbon sources and sulfate reduction. The obtained SRB community was the inoculum to the SRB cultures in main experiment.

Cultures of sulfate-reducing microbial communities. Anaerobic batch cultures in modified liquid Postgate $\mathrm{C}$ medium were carried out in 0.51 glass bottles filled to 0.251 volume. The bottles were tightly sealed with rubber stoppers pierced with needles connected permanently to syringes, which were used to introduce the inoculum and to collect samples under $\mathrm{N}_{2}$. The inoculum-to-medium ratio was 1:10. The anaerobic conditions in the cultures were controlled by addition of resazurin as the oxygen-level indicator. Violet 
Table I

Experimental setup

\begin{tabular}{|c|c|c|c|c|c|c|}
\hline \multirow{2}{*}{ Source of carbon } & \multicolumn{2}{|c|}{ SRB cultures } & \multicolumn{2}{|c|}{ Biotic control } & \multicolumn{2}{|c|}{$\begin{array}{c}\text { Abiotic control } \\
\text { (for diffractometric analysis) }\end{array}$} \\
\hline & Ethanol & Lactate & Ethanol & Lactate & Ethanol & Lactate \\
\hline \multirow[t]{4}{*}{$\mathrm{Zn}^{2+}$ concentration $[\mathrm{mg} / \mathrm{l}]$} & 100 & 100 & \multirow[t]{4}{*}{0} & \multirow[t]{4}{*}{0} & 100 & 100 \\
\hline & 200 & 200 & & & 200 & 200 \\
\hline & 500 & 500 & & & 500 & 500 \\
\hline & 700 & 700 & & & 700 & 700 \\
\hline SRB inoculum & $10 \%$ & $10 \%$ & $10 \%$ & $10 \%$ & without inoculum & without inoculum \\
\hline Repetitions & $2 \times$ & $2 \times$ & $2 \times$ & $2 \times$ & $1 \times$ & $1 \times$ \\
\hline
\end{tabular}

colour indicated that the culture contained oxygen, and its absence pointed to anaerobic conditions. The experiment was carried out in two variants, one with ethanol and the other with lactate as the sole carbon source $(4000 \mathrm{mg} / \mathrm{l})$. The control batch consisted of SRB cultures without zinc (biotic control) and cultures with zinc and without SRB (abiotic control). The abiotic controls were conducted in order to analyze of mineral phases formed without microbial activity. All the SRB cultures were stationary and were conducted in the modified Postgate $\mathrm{C}$ medium. The experiment and the chemical determinations in cultures were made in duplicate. The experimental setup is shown in Table I.

Media. A modified liquid Postgate $\mathrm{C}$ medium (Postgate, 1984), composed of: $\mathrm{KH}_{2} \mathrm{PO}_{4}(500 \mathrm{mg} / \mathrm{l})$, $\mathrm{NH}_{4} \mathrm{Cl}(1000 \mathrm{mg} / \mathrm{l}), \mathrm{CaCl}_{2}(60 \mathrm{mg} / \mathrm{l}), \mathrm{MgSO}_{4}(60 \mathrm{mg} / \mathrm{l})$, $\mathrm{FeSO}_{4}(100 \mathrm{mg} / \mathrm{l}), \mathrm{Na}_{2} \mathrm{SO}_{4}(4500 \mathrm{mg} / \mathrm{l})$ without yeast extract and citrate, and a minimal medium (Wolicka and Kowalski, 2006), composed of $\mathrm{NH}_{4} \mathrm{Cl}(1000 \mathrm{mg} / \mathrm{l})$ and $\mathrm{Na}_{2} \mathrm{SO}_{4}(4500 \mathrm{mg} / \mathrm{l})$, were used in the experiment. Lactate $(4000 \mathrm{mg} / \mathrm{l})$ or ethanol $(4000 \mathrm{mg} / \mathrm{l})$ were added to both media as the sole carbon sources. Resazurin $(1 \mathrm{mg} / \mathrm{l})$ was added to all cultures in order to control the level of oxidation. The medium did not contain yeast extract or sodium citrate. $\mathrm{Zn}^{2+}$ was added in concentrations of 100, 200, 500 and $700 \mathrm{mg} / \mathrm{l}$ to a modified Postgate $\mathrm{C}$ medium. $\mathrm{Zn}^{2+}$ was added as zinc (II) chloride.

Sulfate determinations were made using the turbidimetric method after reaction with barium chloride in a Thermo spectrophotometer at $\lambda=400 \mathrm{~nm}$ wavelength (Greenberg et al., 1985).

Protein determinations in the cultures were made using the Lowry method after a biuret test enhanced by the Folin-Ciocalteau reagent in a Thermo spectrophotometer at $\lambda=670 \mathrm{~nm}$ (Genesys 10Vis, Thermo). The samples $(5 \mathrm{ml})$ for determination were previously sonicated $(30 \mathrm{kHz}, 30 \mathrm{~s})$ in order to determine total protein from cultures. The measurement was performed as follows. The $1 \mathrm{ml}$ of sonicated sample was put into glass tubes and $5 \mathrm{ml}$ of reagent $\left(49 \mathrm{ml} 2 \% \mathrm{Na}_{2} \mathrm{CO}_{3}\right.$ in $0.1 \mathrm{M} \mathrm{NaOH}+0.5 \mathrm{ml} 2 \%$ potassium sodium tartrate
$+0.5 \mathrm{ml} \mathrm{1 \%} \mathrm{CuSO}_{4}$ ) was added. After $5 \mathrm{~min} ., 0.2 \mathrm{ml}$ of Folin-Ciocalteau reagent (POCH, Gliwice, Poland) was added and immediately mixed. After $5 \mathrm{~min}, 0.2 \mathrm{ml} 6 \mathrm{M}$ $\mathrm{NaOH}$ was added and mixed, then the absorbance of the colored solution was immediately measured spectrophotometrically. Protein measurements were used as an indicator of biomass.

Zinc determinations in stationary cultures. The determinations were made using the Thermo spectrophotometer with application of available kits for determining zinc concentrations (Merck Zinc Test with a pyridylazo naphthol derivative).

Analysis of the post-culture sediments. After incubation, the cultures were centrifuged at $10000 \times \mathrm{g}$, and the obtained post-culture sediment was dried at $30^{\circ} \mathrm{C}$ under $\mathrm{N}_{2}$. The samples were next ground in an agate mortar, and their mineral composition was determined using X-ray powder diffraction in a diffractometer (Panalytical X' Pert PRO MPD). The diffractometric analysis was conducted on 10 samples of post-culture sediments; five were taken from cultures that used ethanol as the sole carbon source, and five were taken from cultures with lactate as the sole carbon source. Additionally, the analysis of sediments from abiotic control with $\mathrm{Zn}^{2+}$ (500 and $700 \mathrm{mg} / \mathrm{l}$ ) were also conducted.

Molecular analysis of the selected sulfidogenous microorganism communities. The taxonomic composition of the sulfate-reducing bacterial communities was obtained using molecular analysis. Isolation of chromosome DNA and analysis of gene 16S rRNA fragments were carried out according to commonly applied procedures of Collins et al. (1991). Bacterial DNA was isolated from a fluid culture of microorganisms with a commercial kit for chromosomal DNA isolation (A\&A Biotechnology). The purity and concentration of the resulting DNA preparation were determined spectrophotometrically at $260 \mathrm{~nm}$. Primers specific for bacterial 16S rRNA (27F 5'-AGAGTTTGATCCTGGCTCAG-3' and 1492R 5'-GGTTACCTTGTTACGACTT-3') were used to amplify a 1540-bp segment from the $16 \mathrm{~S}$ rRNA gene. The PCR reaction was made 
using the GeneAmp PCR reagent kit with AmpliTaq DNA polymerase (Invitrogen). Amplification products were purified using the Wizard Purification System (Promega) and analyzed by electrophoresis. After amplification, the material was sequenced using the ABI 3730 Genetic Analyzer with application of the Perkin Elmer sequencing kit. The resulting nucleotide sequences were compared with gene $16 \mathrm{~S}$ rRNA sequences available in the National Centre for Biotechnology Information (NCBI) database using NCBI's Blast 2.0 program and showed $99 \%$ homology with the corresponding sequences among different anaerobic species.

\section{Results and Discussion}

The influence of zinc concentrations on the activity of selected SRB communities is presented in Figs. 1 and 2 and the changes of concentration of sulphate and protein in control cultures are presented in Fig. 3. The initial concentration of protein at the level of about $2000 \mathrm{mg} / \mathrm{l}$ was derived from the inoculum. A slight increase of protein concentration and decrease of sulfate concentration was observed in cultures where the $\mathrm{Zn}$ concentration was $100 \mathrm{mg} / \mathrm{l}$ on a medium with ethanol as the sole carbon source (Fig. 1). Such trends were not observed in the remaining cultures, regardless of the applied carbon source. A slight increase of protein concentration and decrease of sulfate concentration was noted in the control batch. Based on the obtained results, it can be stated, that the zinc concentration tolerated by the isolated SRB community was $100-200 \mathrm{mg} / \mathrm{l}$.

The results may partially confirm existing literature data. Zinc is a metal that may hampers in higher concentrations the metabolic activity of various microorganisms, including SRB (Utgikar et al., 2002), but on the other hand many mechanisms responsible for metal-ion resistance in bacteria have been described (Brocklehurst and Morby, 2000). SRB are effective in reducing the sulfate concentration and neutralizing its acidity. Furthermore, most of the heavy metals present in acidic mine drainage can be precipitated as insoluble sulfides using biogenic sulfide produced by sulfate reduction (Barton and Tomei, 1995; Costa et al., 2008; Martins et al., 2009a). The reported toxic concentrations of heavy metals to sulfate reducers range from a few $\mathrm{mg} / \mathrm{l}$ to $100 \mathrm{mg} / \mathrm{l}$ (Loka Bharathi et al., 1990; Poulson et al., 1997; Utgikar et al., 2001). Data in the literature indicate that various concentrations of zinc inhibit SRB activity. Radhika et al. (2006) estimated that the concentration of zinc lethal to SRB is about $210 \mathrm{mg} / \mathrm{l}$. Castillo et al. (2012) isolated communities from sediments in two acid streams draining the Iberian Pyrite Belt, in which zinc occurred at con-

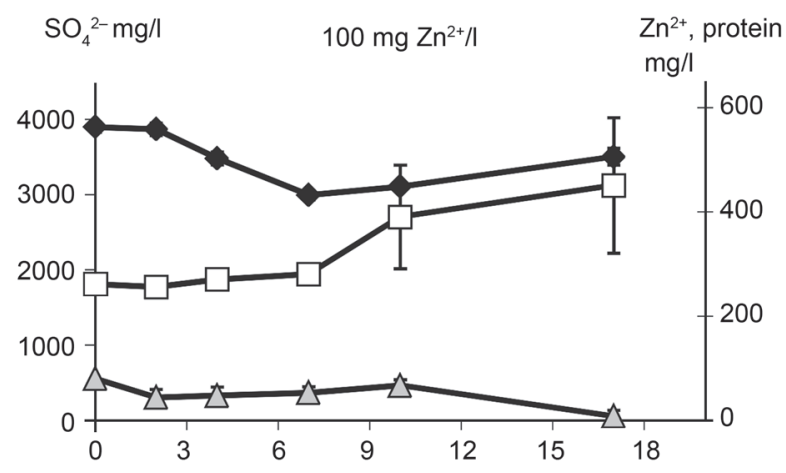

$\mathrm{SO}_{4}{ }^{2-} \mathrm{mg} / \mathrm{l} \quad 200 \mathrm{mg} \mathrm{Zn^{2+ } / /}$

$\mathrm{Zn}^{2+}$, protein $\mathrm{mg} / \mathrm{l}$
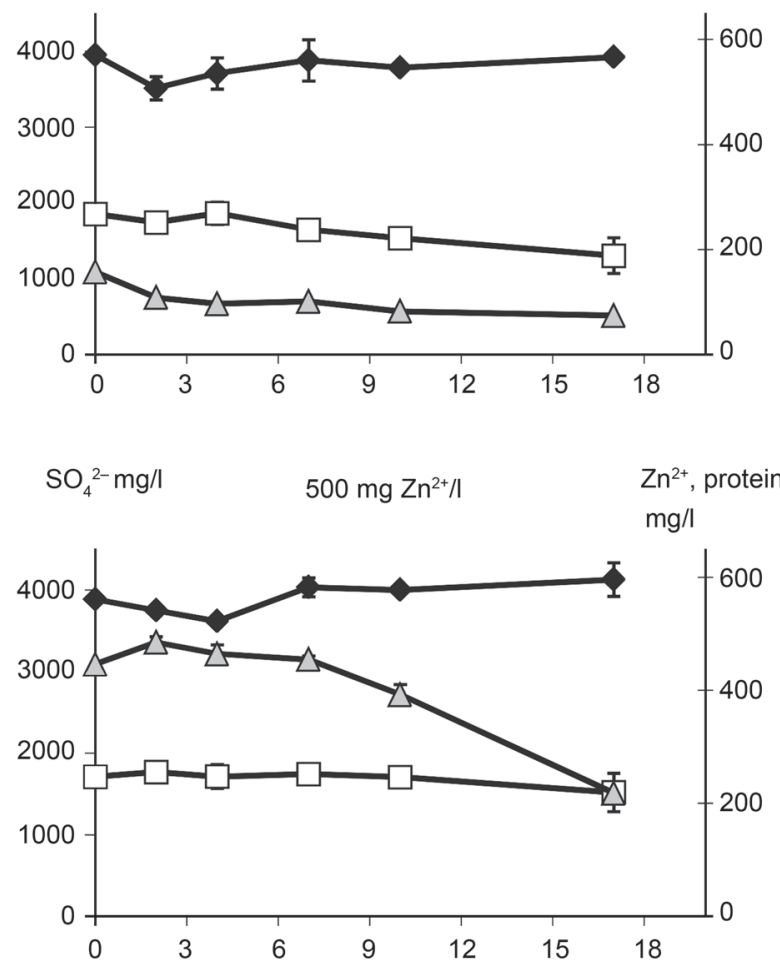

$\mathrm{SO}_{4}{ }^{2-} \mathrm{mg} / \mathrm{l}$

$700 \mathrm{mg} \mathrm{Zn}{ }^{2+} / \mathrm{I}$

$\mathrm{Zn}^{2+}$, protein

$\mathrm{mg} / \mathrm{l}$

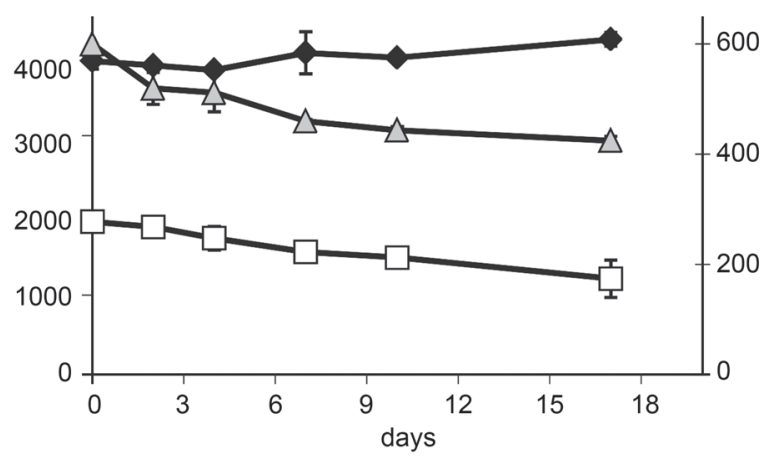

$\neg$ sulphate $\quad \square$ protein $\quad-\mathrm{Zn}$

Fig. 1. Concentration changes of sulfate, protein and zinc in sulfidogenic microbial cultures with ethanol as the sole organic carbon source at variable initial concentrations of $\mathrm{Zn}^{2+}(100,200$, $500,700 \mathrm{mg} / \mathrm{l})$. Standard deviation has been marked 

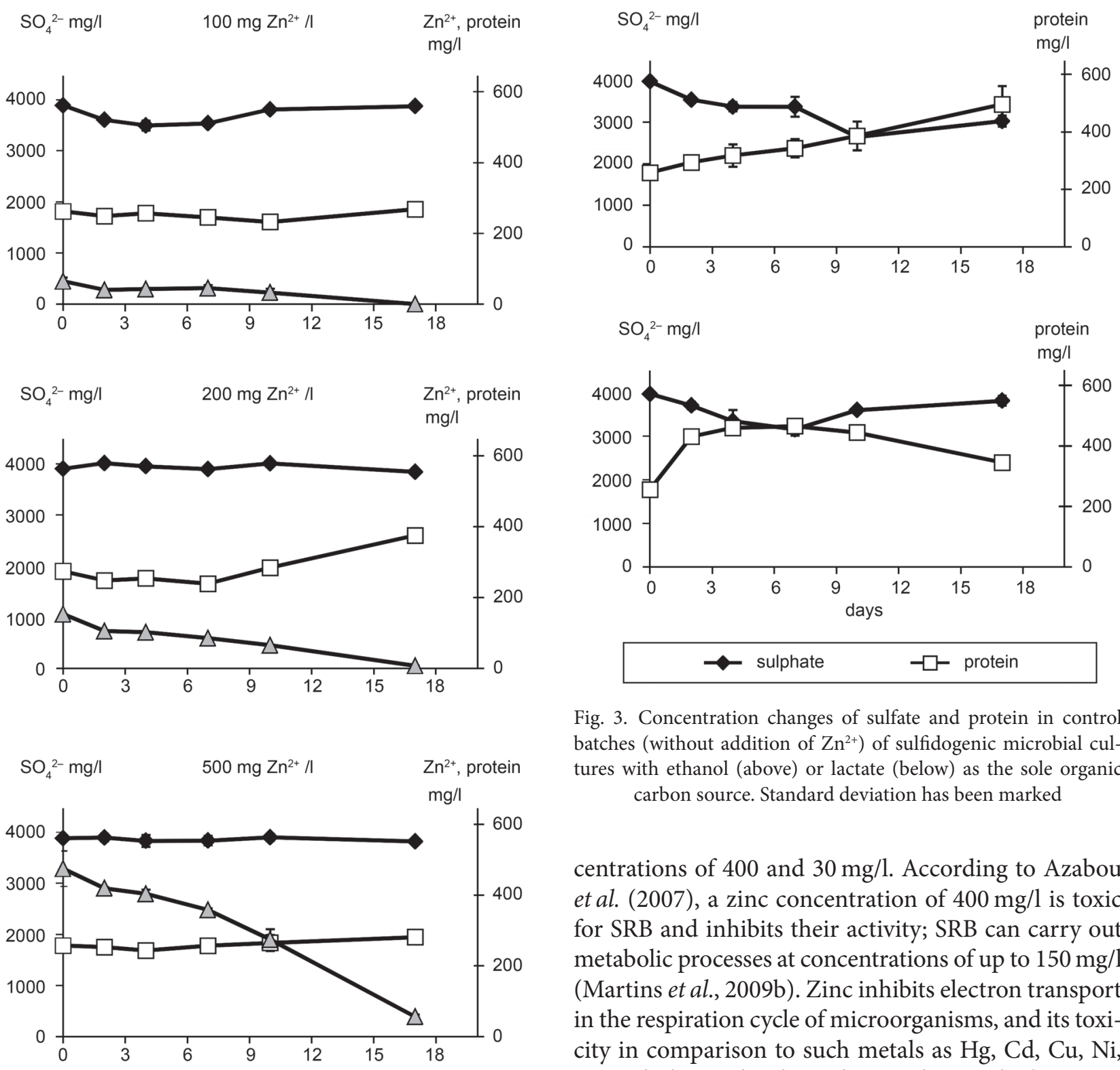

Fig. 3. Concentration changes of sulfate and protein in control batches (without addition of $\mathrm{Zn}^{2+}$ ) of sulfidogenic microbial cultures with ethanol (above) or lactate (below) as the sole organic carbon source. Standard deviation has been marked

centrations of 400 and $30 \mathrm{mg} / \mathrm{l}$. According to Azabou et al. (2007), a zinc concentration of $400 \mathrm{mg} / \mathrm{l}$ is toxic for SRB and inhibits their activity; SRB can carry out metabolic processes at concentrations of up to $150 \mathrm{mg} / \mathrm{l}$ (Martins et al., 2009b). Zinc inhibits electron transport in the respiration cycle of microorganisms, and its toxicity in comparison to such metals as $\mathrm{Hg}, \mathrm{Cd}, \mathrm{Cu}, \mathrm{Ni}$, $\mathrm{Co}$ and $\mathrm{Pb}$ is rather low. There is data in the literature on the influence of zinc on SRB activity, but there are
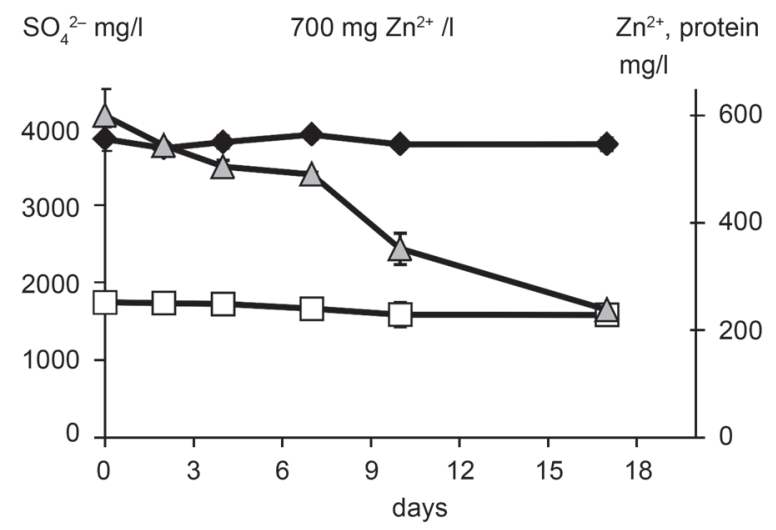

sulphate

$\neg-$ protein $\quad-\square \mathrm{Zn}$

Fig. 2. Concentration changes of sulfate, protein and zinc in sulfidogenic microbial cultures with lactate as the sole organic carbon source at variable initial concentrations of $\mathrm{Zn}^{2+}(100,200$, $500,700 \mathrm{mg} / \mathrm{l})$. Standard deviation has been marked no reports that simultaneously discuss the influence of zinc concentration on SRB activity and the types of the resulting mineral phases.

In the present study, the determination of the influence of $\mathrm{Zn}^{2+}$ on the mineral composition of post-culture sediments was conducted. The presence of zinc sulfide was determined in the post-culture sediments from cultures with ethanol as the sole carbon source and $100 \mathrm{mg}$ $\mathrm{Zn} / \mathrm{l}$ (Fig. 4). In the culture, where the zinc concentration was $200 \mathrm{mg} / \mathrm{l}$, sphalerite $(\mathrm{ZnS})$ as well as elemental sulfur were observed. It could be that elemental sulfur is formed by sulfidogenic bacterial communities. In natural ecosystems, the sulfur cycle should be in balance, meaning that the amount of sulfide that is oxidized should correspond to the amount of sulfate that is reduced. Such a balance can be found in a sulfuretum. This is a syntrophical bacterial community in which $\mathrm{H}_{2} \mathrm{~S}$ produced by sulfate-reducing bacteria is reoxidized 


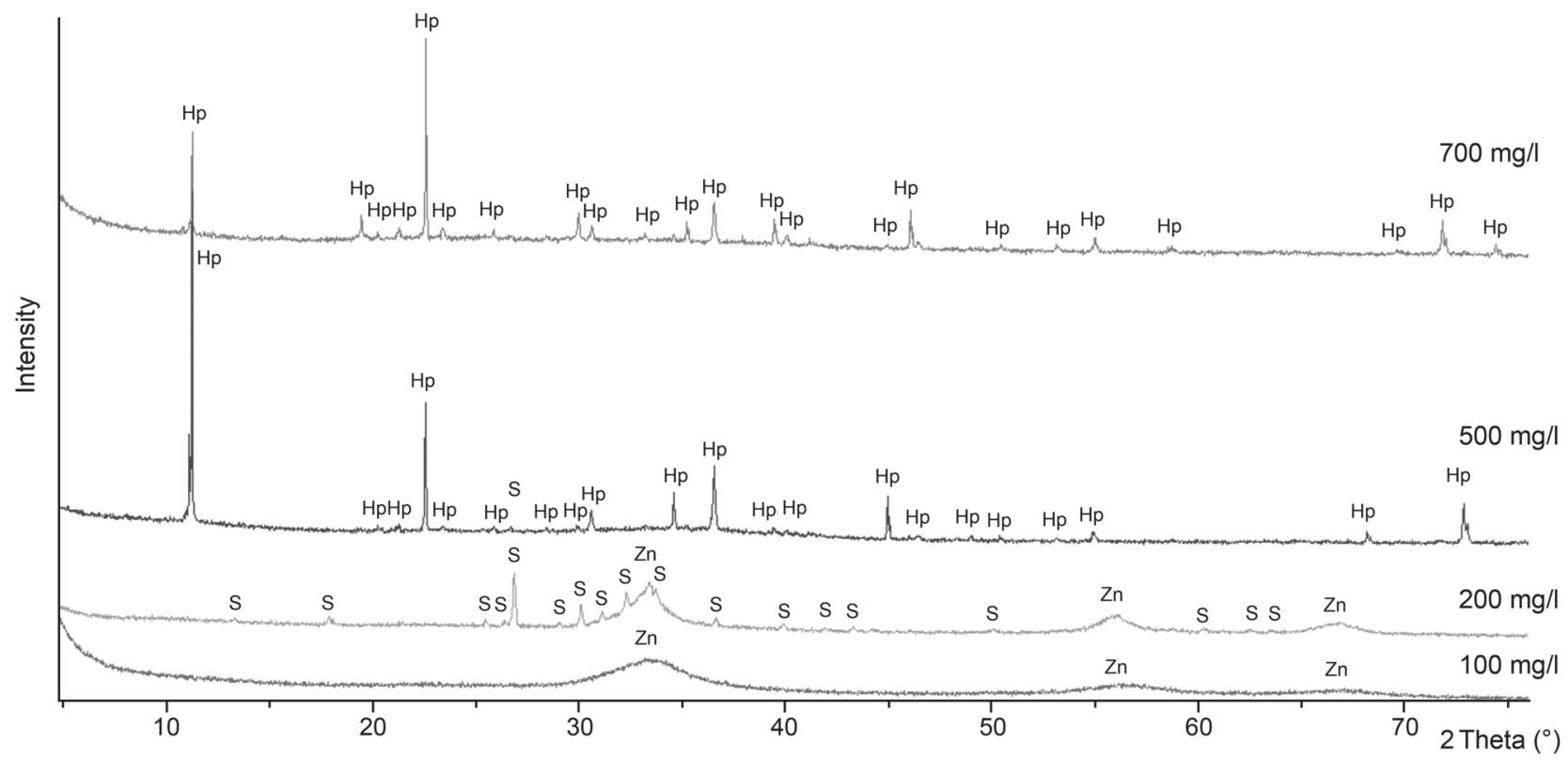

Fig. 4. X-ray powder diffractograms of post-culture sediments in cultures of selected SRB communities on a modified Postgate medium with ethanol as the sole carbon source and with addition of $\mathrm{Zn}^{2+}$ in concentrations of 100-700 mg/l. Symbols: $\mathrm{Zn}$, sphalerite $\mathrm{ZnS}$; Hp, hopeite $\mathrm{Zn}_{3}\left(\mathrm{PO}_{4}\right)_{2} \cdot \mathrm{H}_{2} \mathrm{O} ; \mathrm{S}$, sulfur

by the sulfur-compound-oxidizing bacteria. This process is not as common in the natural environment as dissimilation sulfate reduction, but it should not be excluded (Roy and Trudinger, 1970; Hedderich et al., 1999). The remaining cultures containing more than $200 \mathrm{mg} \mathrm{Zn}{ }^{2+} / 1$ contained hopeite $\left[\mathrm{Zn}_{3}\left(\mathrm{PO}_{4}\right)_{2} \cdot \mathrm{H}_{2} \mathrm{O}\right]$, which was probably formed by abiotic processes because the medium used for SRB growth contained phosphates $\left(\mathrm{KH}_{2} \mathrm{PO}_{4}\right)$. The abiotic control batch did not contain any mineral phases except hopeite. Hopeite was detected in abiotic controls containing 500 and $700 \mathrm{mg} \mathrm{Zn}^{2+} / 1$.

On a medium with lactate as the sole carbon source (Fig. 2), significant SRB activity could not be observed, but a slight increase of protein content in the cultures worth noting, pointing to the development of microorganisms accompanying SRB that were capable of activity in the presence of high zinc concentrations. The significant decrease of zinc concentration may have been the effect of this microflora activity, although this fact cannot be unambiguously confirmed. The effect of inoculum can be appear only at initial stage of experiment, when it can be observed the slight decrease of zinc concentration. A considerable impediment in the analysis of the results is also the lack of determination of the minerals in post-culture sediments that could not be obtained using X-ray diffraction. This lack probably was caused by the low number of mineral phases in the post-culture sediment and precipitation of amorphous or nanostructured chemical compounds, which often accompany EPS organic compounds. Moreau et al. (2007) suggest that formation of mineral aggregates is induced by extracellular metal- binding polypeptides and proteins. Disordered morphological features of zinc sulfides have been described by Gramp etal. (2007), who tested for formation of $\mathrm{Zn}$ sulfides n cultures of SRB.

The 16S rRNA method was applied in order to determine the specific composition of the selected microorganism communities. The analysis indicated the presence of Desulfovibrio spp., Desulfobulbus spp. and Desulfotomaculum spp. in the communities. Some of these microorganisms are capable of sulfate reduction to elemental sulfur, which was confirmed by diffractometric analysis of the post-culture sediments. Moreover, removal of hydrogen sulfide from the environment by formation of sulfides results in a decrease of the reducing conditions that are indispensable for SRB activity (Labrenz et al., 2000).

Conclusions. The results supplement the knowledge of the mineral-forming processes taking place in cultures with various concentrations of zinc and indicate a possibly significant participation of SRB in the processes taking place in the natural environment under hypergenic conditions. Moreover, they indicate the possible application of SRB in the treatment of acid mine drainage, but the high concentrations of metals potentially can limit the SRB activity. Cultures with zinc showed strong inhibition of the activity of selected sulfidogenic communities in cultures con-

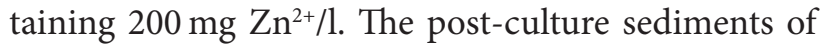
cultures in a Postgate medium with ethanol as the sole carbon source contained sphalerite (cultures containing

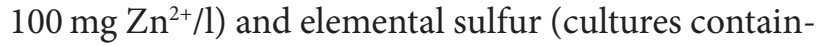


ing $\left.200 \mathrm{mg} \mathrm{Zn}^{2+} / \mathrm{l}\right)$. In the remaining cultures, in which the content of zinc ions was much higher, the postculture sediments contained zinc phosphate formed by abiotic processes. The results confirm the participation of SRB in mineral-forming processes in environments containing zinc.

\section{Acknowledgments}

We would like to thank the Polish Oil \& Gas Company, especially Jozef Potera and Tadeusz Kozimor from the Sanok Branch and Zbigniew Ząbkiewicz from Warsaw. This work was supported by the Institute of Geochemistry, Mineralogy and Petrology under BST Grant No. IGMiP-28-2012. The authors thank Reviewers for their remarks and comments which have improved this article.

\section{Literature}

Azabou S., T. Mechichi and S. Sayadi. 2007. Zinc precipitation by heavy-metal tolerant sulfate-reducing bacteria enriched on phosphogypsum as a sulfate source. Minerals Engineering 20: 173-178. Barton L.L. and F.A. Tomei. 1995. Characteristics and activities of sulfate reducing bacteria, pp. 1-32. In: L. L. Barton (eds). Sulfate Reducing Bacteria. Plenum Press, Chap 1. New York.

Becking L.G.M.B. and D. Moore. 1961. Biogenic sulfides. Economic Geology 56: 259-272.

Brocklehurst K.R. and A.P. Morby. 2000. Metal-ion tolerance in Escherichia coli: analysis of transcriptional profiles by gene-array technology. Microbiology 146: 2277-2282

Castillo J., R. Pérez-López, M.A. Caraballo, J.M. Nieto, M. Martins, M.C. Costa, M. Olias, J.C. Cerón and R. Tucoulou. 2012. Biologically-induced precipitation of sphalerite-wurtzite nanoparticles by sulfate-reducing bacteria: Implications for acid mine drainage treatment. Science of the Total Environment 423: 176-184.

Collins M.D., S. Wallbanks, D.J. Lane, J. Shah, R. Nietupski, J. Smida, M. Dorsch and E. Stackebrandt. 1991. Phylogenetic analysis of the genus Listeria based on reverse transcriptase sequencing of 16S rRNA. International Journal of Systematic and Evolutionary Microbiology 41: 240-246.

Costa M.C., M. Martins, C. Jesus and J.C. Duarte. 2008. Treatment of acid mine drainage by sulphate-reducing bacteria using low cost matrices. Water Air Soil Pollut. 189: 149-162.

Drury W.J. 1999. Treatment of acid mine drainage with anaerobic solid-substrate reactors. Water Environmental Research 71: 1244-1250. Feio M.J., V. Zinkevic, I.B. Beech, E. Llobet-Brossa, P. Eaton, J. Schmitt and J. Guezennec. 2004. Desulfovibrio alaskensis sp. nov., a sulphate reducing bacterium from a soured oil reservoir. International Journal of Systematic and Evolutionary Microbiology 54: 1747-1752.

Fosmire G.J. 1990. Zinc toxicity. American Journal Clinical Nutrition 51: 225-222.

Gramp J.P., J.M. Bigham, K. Sasaki and O.H. Touvien. 2007. Formation of Ni- and Zn-sulfides in cultures of Sulfate-Reducing Bacteria. Geomicrobiology Journal 24: 609-614.

Greenberg A.E., R.R. Trussell and L.S. Clesceri. 1985. Standard methods for the examination of water and wastewater, pp. 11-20. APHA-AWWWA-WPCF, Washington, DC.

Hao O.J, J.M. Chen, L. Huang and R.L. Buglass. 1996. Sulfatereducing bacteria. Critical Reviews in Environmental Science and Technology 26: 155-187.

Hedderich R., O. Klimmek, A. Kroger, M. Dirmeier, M. Kelller and O. Stetter. 1999. Anaerobic respiration with elemental sulfur and with disulfides. FEMS Microbiology Reviews 22: 353-381.
Jonson D.B. and K.B. Halleberg. 2003. The microbiology of acidic mine wasters. Res. Microbology 154: 466-473.

Kaksonen A.H. and J.A. Puhakka. 2007. Sulfate reduction based bioprocesses for the treatment of acid mine drainage and the recovery of metals. Engineering in Life Sciences 7: 541-564.

Labrenz M., G.K. Druschel, T. Thomsen-Ebert, B. Gilbert, S.A. Welch, K.M. Kemmer, G.A. Logan, R.E. Summons, G. De Stasio, P.L. Bond and others. 2000. Formation of sphalerite (ZnS) deposits in natural biofilms of sulfate-reducing bacteria. Science 290: 1744-1747.

Ledin M. and K. Pedersen. 1996. The environmental impact of mine wastes - Roles of microorganisms and their significance in treatment of mine wastes. Earth Science Reviews 41: 67-108.

Loka Bharathi P.A., V. Sathe and D. Chandramohan. 1990. Effect of lead, mercury and cadmium on a sulphate-reducing bacterium. Environmental Pollutants 67 (4): 361-74.

Luptakova A. and M. Kusnierova. 2005. Bioremediation of acid mine drainage contaminated by SRB. Hydrometallurgy 77: 97-102. Martins M., M.L. Faleiro, R.J. Barros, A.R. Verissimo, M.A. Barreiros and M.C. Costa. 2009a. Characterization and activity studies of highly heavy metal resistant sulphate-reducing bacteria to be used in acid mine drainage decontamination. Journal of Hazardous Materials 166: 706-713.

Martins M., M.L. Faleiro, R.J. Barros, A.R. Verissimo and M.C. Costa. 2009b. Biological sulphate reduction using food industry wastes as carbon sources. Biodegradation Journal 20 (4): 559-567. Moreau J.W., P.K. Weber, M.C. Martin, B. Gilbert, I.D. Hutcheon and J.F. Banfield. 2007. Extracellular proteins limit the dispersal of biogenic nanoparticles. Science 316: 1600-1603.

Moreau J.W., R.I. Webb and J.F. Banfield. 2004. Ultrastructure, aggregation-state, and crystal growth of biogenic nanocrystalline sphalerite and wurtzite. American Mineralogist 89: 950-960.

Ong S-A., E. Toorisaka, M. Hirata and T. Hano. 2010. Adsorption and toxicity of heavy metals on activated sludge. Science Asia 36: 204-209.

Postgate J.R. 1984. The sulphate reducing bacteria, pp. 1-159. $2^{\text {nd }}$ ed. Cambridge University Press, Cambridge.

Poulson S.R., P.J.S. Colberg and J.I. Drever. 1997. Toxicity of heavy metals (Ni, Zn) to Desulfovibrio desulfuricans. Geomicrobiology Journal 14: 41-49.

Radhika V., S. Subramanian and K.A. Natarajan. 2006. Bioremediation of zinc using Desulfotomaculum nigrificans: Bioprecipitation and characterization studies. Water Research 40: 3628-3636.

Roy A.B and P.A. Trudinger. 1970. The biochemistry of inorganic compounds of sulphur, pp. 1-399. Cambridge University Press, Cambridge. Utgikar V.P., B-Y. Chen, N. Chaudhary, H.H. Tabak, J.R. Hainjes and R. Govind. 2001. Acute toxicity of heavy metals to acetateutilizing mixed cultures of sulfate-reducing bacteria: EC100 and EC500. Environmental Toxicology and Chemistry 20: 2662-2669.

Utgikar V.P., S.M. Harmon, N. Chaudhary, H.H. Tabak, R. Govind and J.R. Haines. 2002. Inhibition of sulfate-reducing bacteria by metal sulfide formation in bioremediation of acid mine drainage. Environomental Toxicolology 17: 40-48.

Vainshtein M., H. Hippe and R.M. Kroppenstedt. 1992. Cellular fatty acid composition of Desulfovibrio species and its use in classification of sulfate-reducing bacteria. Syst. Applied Microbiology 15: 554-556.

Wolicka D. and W. Kowalski. 2006. Biotransformation of phosphogypsum in petroleum-refining wastewaters. Polish J. Environ. Stud. 15 (2): 355-360.

Zinkevich V., I. Bogdarina, H. Kang, M. Hill, R. Tapper and I.B. Beech. 1996. Characterisation of exopolymers produced by different isolates of marine sulphate-reducing bacteria. Int. Biodeterior Biodegrad 37: 163-172. 
